\title{
THE STUDY ON LOADS ON AN AIRCRAFT PISTON ENGINE CONTINENTAL MOTORS IOF-240-B5B IN TRAINING FLIGHTS
}

\author{
Łukasz GRABOWSKI ${ }^{1}$, Zbigniew CZYŻ ${ }^{2}$, Marcin PORZAK ${ }^{3}$ \\ ${ }^{1,2}$ Dept of Thermodynamics, Fluid Mechanics and Aviation Propulsion Systems, \\ Lublin University of Technology; Poland \\ ${ }^{3}$ KS Engineering Technology Sp. z o. o., Lublin, Poland
}

Received 2 July 2016; revised 6 June 2017; accepted 24 August 2017

\begin{abstract}
This investigation presents the development of a model of a flight envelope for a piston engine aircraft. The study covers performing necessary tests and measurements of the selected operating parameters of the engine piston and an analysis of the results. The paper describes also a mission and aircraft manoeuvres. This investigation enables us to study loads on an aircraft piston engine, i.e. Continental Motors IOF-240-B5B, mounted in the Liberty XL2 by Liberty Aerospace.
\end{abstract}

Keywords: engines, planes, aircraft, load study, FADEC, rotational speed, mean head temperature, intake manifold pressure.

\section{Introduction}

Correct energy management is presently a basic focus of the majority of the studies on aspects of the operation of aircraft engines. This means that efficient engine operation combined with low emissions is more important than more power to reduce light aircraft fuel consumption with a relatively small decline in cruising speed and to reduce occurring operating costs. Also, following this tendency, engine head temperature should be reduced by, e.g. correct energy management and an appropriately selected fuel mixture, which should lead to engine head better life time and also to reduce the cost to maintain the engine in continuing airworthiness (Brender, Carney 2013; Rice 1958). The thermodynamic aspects of aircraft spark ignition engines have already been well researched and a certain knowledge on them is provided by the studies: Stone (2012); Kroes, Wild (1994) and Crane (2010). The most efficient energy management (economical flight) usually generates up to a $20 \%$ difference in fuel consumption relative to that of the operating point at maximum power (Hirschman 2009). As discussed in works by Hirschman (2009) and Braly (2016), the attempt to achieve highly efficient flight can reduce flight speed by from 5 to $10 \%$. Although a power-to-weight ratio is lower in piston engines than in turbine ones, this difference, according to Dudziak (2013), decreases with increased flight time.
While the unmanned aircraft, typically used for relatively short missions (often shorter than an hour), could be fitted with turbine engines for economic reasons (Wendeker, Czyż 2016; Dudziak 2013), piston engines remain a basic drive unit for longer missions, especially manned ones. Accordingly, piston engines could be successfully applied even in today's aircraft designs. For example, the ILX-27, a helicopter developed by Institute of Aviation, Air Force Institute of Technology and the Military Aviation Plant No. 1 in Łódź (Wendeker, Czyż 2013; Hajduk, Sabak 2013), is equipped with a single piston engine known as Lycoming 0-540-F1B5 of $191 \mathrm{~kW}(260 \mathrm{hp})$.

Safety is definitely a fundamental factor behind designing aircraft engines. Aircraft such as airplanes are very complex structures but accidents due to strictly maldesigned aircraft are rare. The majority of aviation accidents results from failed individual components in systems that generate and transfer power. Accidents that result in destroyed aircraft and casualties are often due to damaged engines (Turan, Karc1 2009; Bhaumik et al. 2002, 2008; ATSB 2007; Lourenço et al. 2008; Findlay, Harrison 2002).

This paper presents a model of a flight envelope of an aircraft. The flight envelope covers a statistical description of loads on the engine. This is a record of loads on the engine when the pilot performs various both air and ground

*Corresponding author. E-mail: z.czyz@pollub.pl 
manoeuvres. It is important here to describe these loads and time of individual manoeuvres. These results can be applied to optimize engine operation. Knowing what the engine should achieve under daily operation, one can perfectly design and built it for the required tasks. The concept of flight envelope is universal so it can successfully describe not only the engine but also the entire aircraft and its individual components. This can serve as a basis for designing structures more adapted to specific tasks, more robust and highly optimized.

\section{Research object}

Engine loads under flight conditions are examined here on the Liberty XL2, which is shown in Figure 1. It is a twoseat, low wing aircraft (Ośrodek Kształcenia Lotniczego... 2018) with a single engine. The Liberty XL2 was produced by Liberty Aerospace, transformed later into Discovery Aviation. The aircraft was designed by Ivan Shaw and is the successor to the Europa XS. It is economical in flight and easy to maintain and operate. Our research plane belongs to Aviation Training Centre of Rzeszów Technical University at Jasionka (Poland) and is applied for training flights.

The drive unit of the Liberty XL2 is the Continental Motors IOF-240-B5B - a four-cylinder, horizontally opposed engine of $125 \mathrm{hp}$, incorporating a Full Authority Digital Engine Control (FADEC) (FAA 2007). The research engine, shown in Figure 1, is also equipped with a microprocessor system, power-link, to individually control ignition and injection in each cylinder. Accordingly, the pilot does not need to regulate the composition of the mixture and to heat up the carburettor as well as this system makes it easier to start up a hot engine. Parameters are automatically selected for each rotation of the shaft to achieve the required power and not exceed the limit values. Consequently, very low fuel consumption of around $20 \mathrm{l} / \mathrm{h}$ and increased engine service life (Stelak 2010) are achieved. The engine was designed in 1960 for light aircraft by Continental Motors and first certified on 7 July 1971. Its technical parameters are in Table 1.

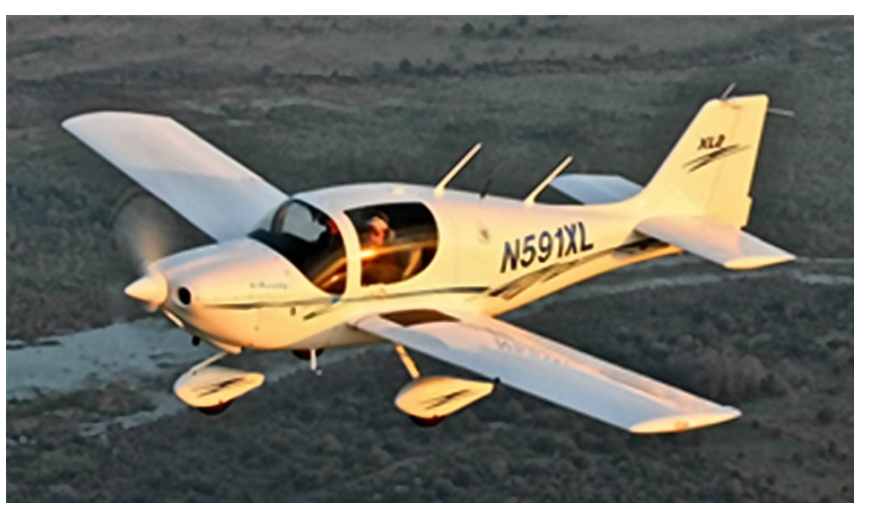

Table 1. Continental Motors IOF-240-B5B technical parameters (Ośrodek Kształcenia Lotniczego... 2018)

\begin{tabular}{|l|c|}
\hline General description & $\begin{array}{c}\text { Four-cylinder, horizontally opposed, } \\
\text { air-cooled aircraft engine }\end{array}$ \\
\hline Bore & $112.7 \mathrm{~mm}$ \\
\hline Displacement & $98.4 \mathrm{~mm}$ \\
\hline Capacity & $3.93 \mathrm{l}$ \\
\hline Weight & $116 \mathrm{~kg}$ \\
\hline Fuel supply system & Aerosance FADEC \\
\hline Fuel & $100 \mathrm{LL}$ AVGAS \\
\hline Cooling & Air-cooled \\
\hline Output power & $125 \mathrm{hp}(93 \mathrm{~kW})$ at $2800 \mathrm{rpm}$ \\
\hline Specific power & $23.66 \mathrm{~kW} / 1$ \\
\hline Compression ratio & $8.5: 1$ \\
\hline Power-to-weight ratio & $0.8 \mathrm{~kW} / \mathrm{kg}$ \\
\hline
\end{tabular}

\section{Research methodology}

This examination focuses on obtaining data on flights of the piston engine aircraft and the key parameters include:

- boost pressure - intake manifold air pressure;

- engine speed;

- cylinder head temperature.

The data on flights was obtained from the FADEC incorporated into the Liberty XL2. The FADEC controls as a whole parameters of the engine and its drive components. If such a type of control applied, a controlling computer completely controls the engine. The pilot cannot control the engine, and in the event of a total system failure, manual control is impossible. The FADEC controls both piston and turbine engines. The system operates by analysing conditions at a given moment to adjust parameters to achieve a constant and most economical operation of the engine. To function correctly, the FADEC analyses data such as (Menne 2007):

- air density;

- throttle position;

- cylinder head temperature.

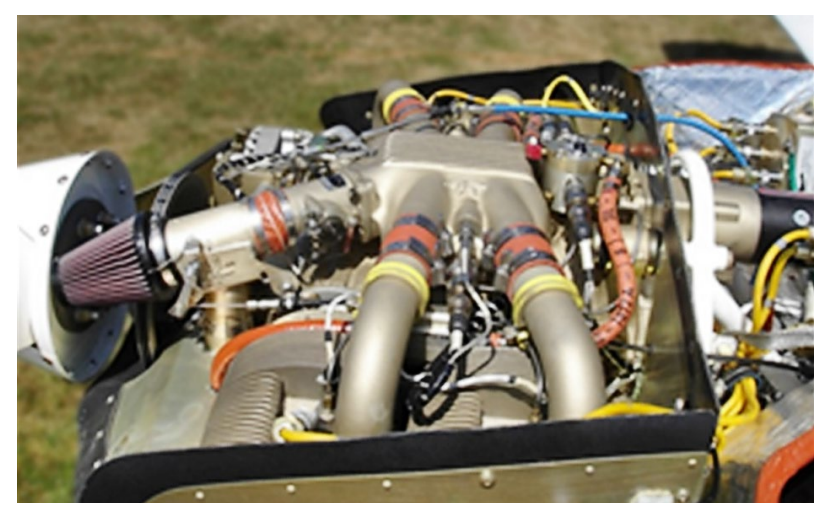

Figure 1. Liberty XL2 in flight (on the left side) and Continental Motors IOF-240-B5B (Ośrodek Kształcenia Lotniczego... 2018) (on the right side) 
The system controls data with a frequency of up to 70 times per second and thus is capable of evaluating, which parameters should be entered so that the engine could achieve the best efficiency. The parameters controlled by the FADEC include in particular (Menne 2007):

- a fuel supply system;

- fuel consumption;

- engine power;

- engine thrust.

Certain additional parameters, which depend on drive unit's complexity are also controlled and include, e.g. rotor blade or propeller pitch or a cooling system. The FADEC also controls engine starting. The FADEC should basically achieve a perfect optimum engine performance corresponding conditions at a given moment (George 2007).

Since the operation of engines and the efficiency of the FADEC are strongly correlated, safety measures are indispensable to protect against potential failures. The basic feature of the safety system is redundancy, which is the duplication of all critical components of a controlling system. If one component fails, the efficient one takes over its tasks. This solution makes the FADEC a "fault tolerant" system, which means that it is designed and built to be capable of operating even if errors occur or its elements fail (FAA 2016). Figure 2 depicts the schematic of FADEC wiring and communication with the remaining aircraft components.

The advantages of the FADEC (Menne 2007) include:

- a more efficient drive unit;

- more efficient fuel consumption;

- automatically protected engines if operations beyond a tolerance range;
- semi-automatic engine starting;

- improved integration of aircraft avionics and propulsion systems;

- improved quality control;

- less parameters to be controlled by the crew;

- automatic emergency assistance to the crew.

The disadvantages of the FADEC (FAA 2016) include:

- an impossible manual engine control - in the event of a total failure of the FADEC, starting or restarting the engine are impossible;

- highly complex control systems;

- high costs of developing systems.

The fact that the Liberty XL2 is applied for training at Aviation Training Centre of Rzeszów Technical University, its individual flights follow the scheme of several stages, according to the data obtained from the FADEC:

- an engine start;

- taxiing into the runway;

- a take-off;

- a climb to the required altitude;

- a cruise and manoeuvres as required by the instructor;

- a descent;

- a final approach;

- landing;

- taxiing on the specified parking space;

- turning off the engine and leaving the aircraft.

If flights repeat, the last two flight stages are replaced by repeating the entire process. This means that landing is followed, instead of taxiing into the parking space, by re-taxiing into the runway and the next regular stages.

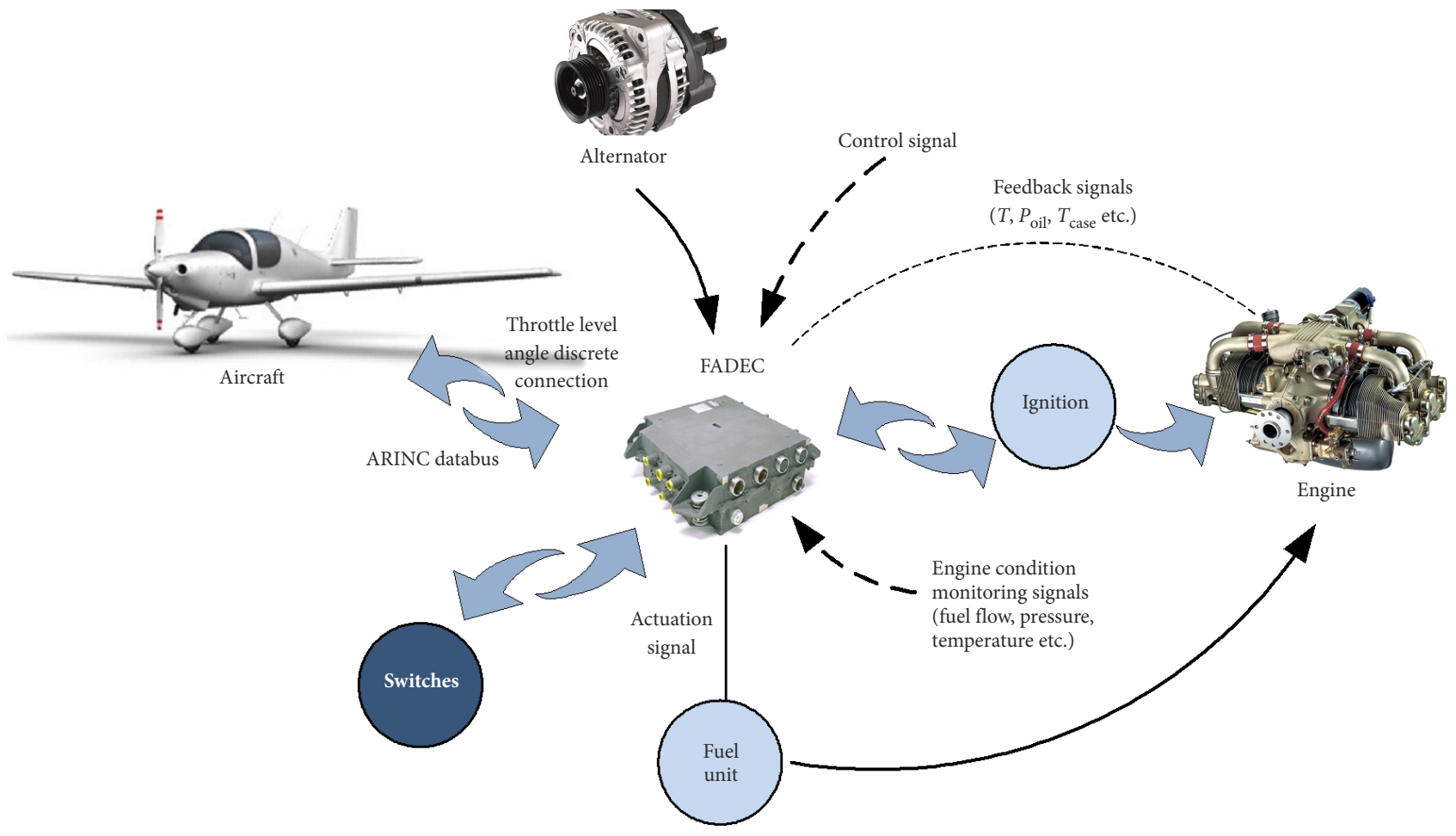

Figure 2. FADEC wiring diagram on the aircraft (study by authors based on Austrian Technik (2017) and Menne (2007)) 
a)

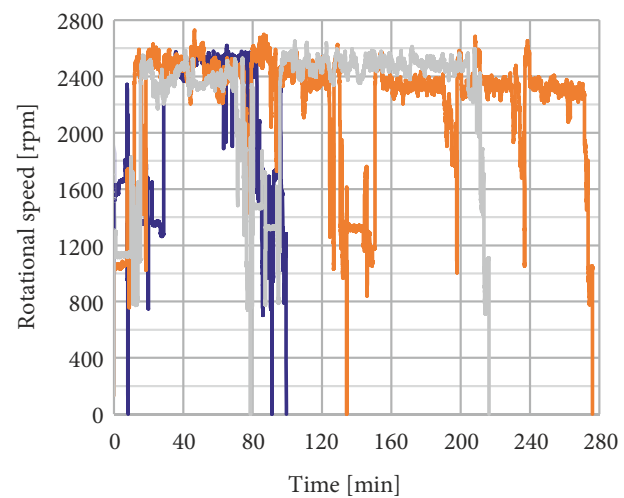

b)

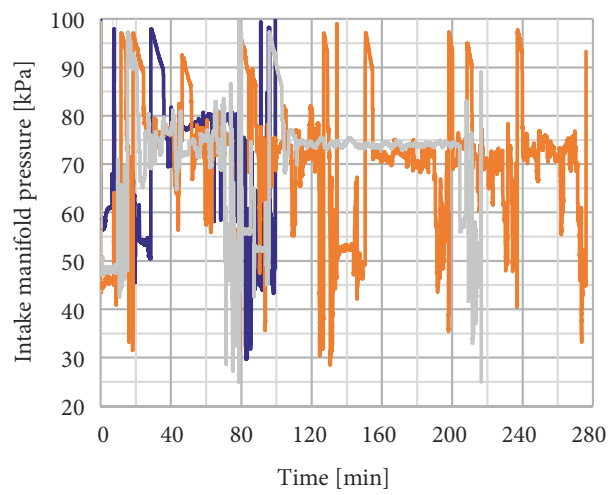

- Flight 1

Flight 2

Figure 3. Engine rotational speed (a) and intake manifold pressure (b) for the Liberty XL2 flights

a)

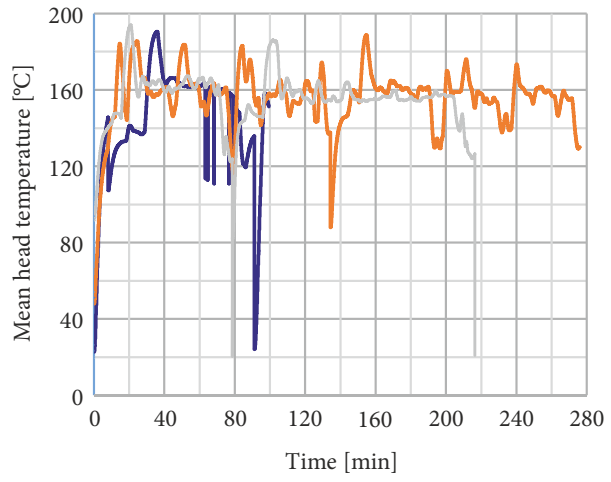

b)

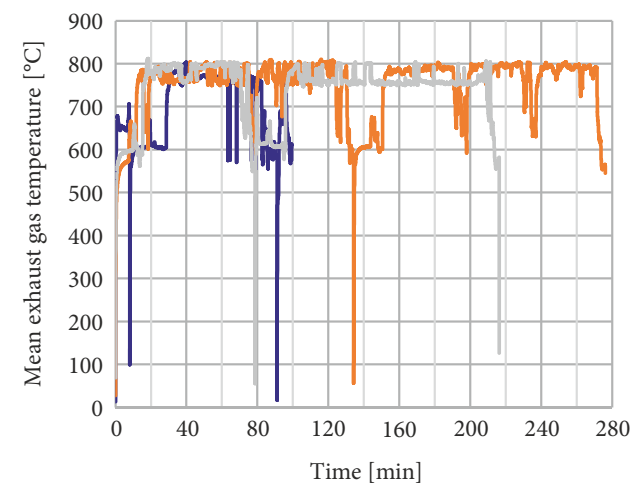

- Flight 1

Flight 2 - Flight 3

Figure 4. Mean head temperature (a) and mean exhaust gas temperature (b) for the Liberty XL2 flights

The data from the FADEC are given in three files with registered parameters. The recording is updated every 1 second and starts when the engine starts and ends when the engine turns off. To facilitate the analysis, each file is assumed to refer to a single flight, which means that a given flight proceeds in a number of take-offs and landings. Flights do not cover time for training breaks. Given the above, the test results are as a recording of the parameters for the three training flights of varied duration with a certain number of take-offs and landings and in-between breaks of random duration.

\section{Research results}

The research data from the FADEC cover three missions of repeated manoeuvres of a take-off and landing. Each mission is regarded as a single flight. The following data from the FADEC is investigated:

- speed [rpm];

- intake manifold pressure [Pa];

- mean head temperature $\left[{ }^{\circ} \mathrm{C}\right]$;

- mean exhaust gas temperature $\left[{ }^{\circ} \mathrm{C}\right]$;

- intake manifold temperature $\left[{ }^{\circ} \mathrm{C}\right]$.

Accordingly, five parameters are obtained for each of the three flights. Figures 3-5 depict the corresponding characteristics.

\section{Research examination}

The study of the research results enables us to design a flight envelope. Regarding the changes of the parameters over time, the beginning and ending of the given stages of the mission are specified and the time of each of these stages are examined. Then, the data are depicted as comparative charts to show the share of time of each stage within the whole mission. This method enables us to design a flight envelope as a table where the given manoeuvres are listed with its average duration within the entire mission of the aircraft. Table 2 shows the time of the given stages and the share of the engine load.

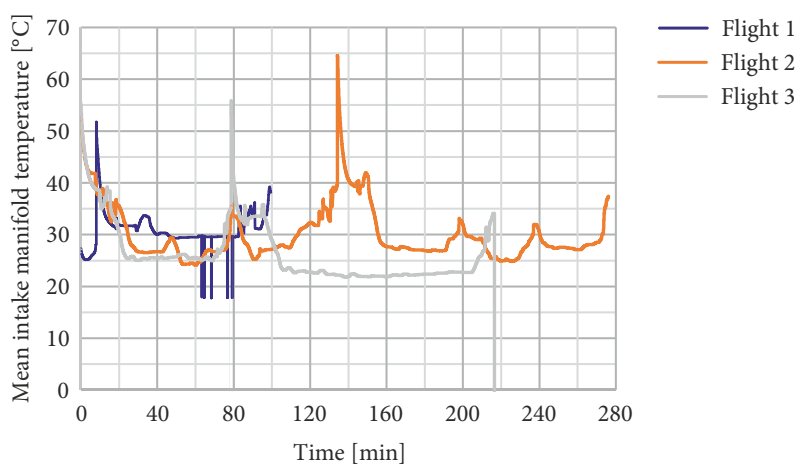

Figure 5. Mean intake manifold temperature for the Liberty XL2 flights 
Table 2. Time of each stage within in the entire mission and the share of the engine load over the given stage

\begin{tabular}{|l|c|c|c|c|}
\hline \multicolumn{5}{|c|}{ Time in minutes over the given stages within the entire mission } \\
\hline & Taxiing [min] & Take-off and climb [min] & Cruise [min] & Descent and landing [min] \\
\hline Flight 1 & 53 & 6 & 40 & 5 \\
\hline Flight 2 & 35 & 13 & 216 & 12 \\
\hline Flight 3 & 33 & 16 & 455 & 12 \\
\hline Total & 121 & 35 & 137 & 9.7 \\
\hline Average & 40.3 & Engine load over the given flight stages & \\
\hline & & Take-off and climb [min] & Cruise [min] & Descent and landing [min] \\
\hline & Taxiing [min] & 95 & 64 & 16 \\
\hline Flight 1 & 10 & 92 & 76 & 19 \\
\hline Flight 2 & 12 & 96 & 68 & 22 \\
\hline Flight 3 & 8 & 94.3 & 69.4 & 19 \\
\hline Average & 10 & &
\end{tabular}

a)

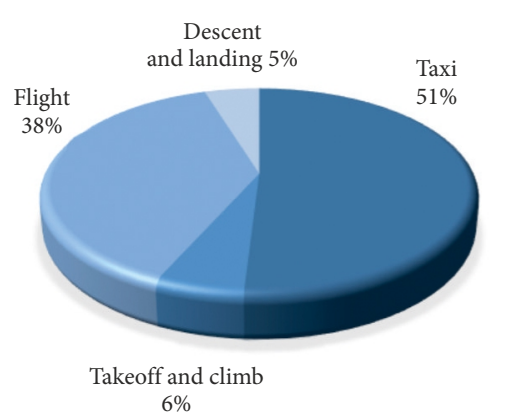

b)

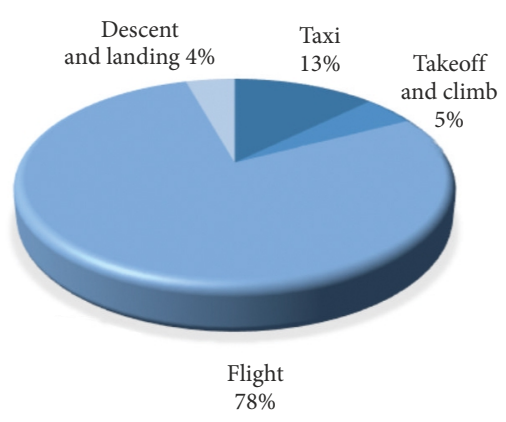

c)

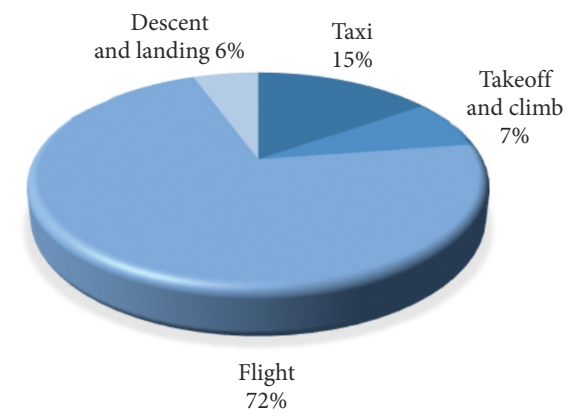

Figure 6. Time share of the given stages within the entire mission for the flights: $\mathrm{a}-$ flight $1 ; \mathrm{b}-$ flight 2 ; $\mathrm{c}-$ flight 3

There are also graphs to show the load on the research aircraft engine over the varied stages of the mission for each of the flights. The engine load is determined by examining the graphs for each of the flights. The zero load is idling and the maximum load is the moment of a total throttle opening over a take-off.

Figure 6 shows the time share of the given stages within the entire mission for all of the Liberty XL2 flights. Figure 7 shows the mean percentage of individual stages relative to the entire mission for all of the Liberty XL2 flights. Figure 8 shows the mean engine load over the given stages for all of the Liberty XL2 flights.

\section{Conclusions}

The result of the research is the model of the flight envelope for the Liberty XL2 with a piston engine Continental Motors IOF-240-B5B. The research results are statistically investigated. The study on the data obtained from the FADEC of the Liberty XL2 shows that the total time of the first flight is $104 \mathrm{~min}$ where the taxiing takes $53 \mathrm{~min}$, the take-off and climb $6 \mathrm{~min}$, the cruise $40 \mathrm{~min}$ and the descent and landing $5 \mathrm{~min}$. The total time of the second flight is $276 \mathrm{~min}$ where the taxiing takes $35 \mathrm{~min}$, the take-

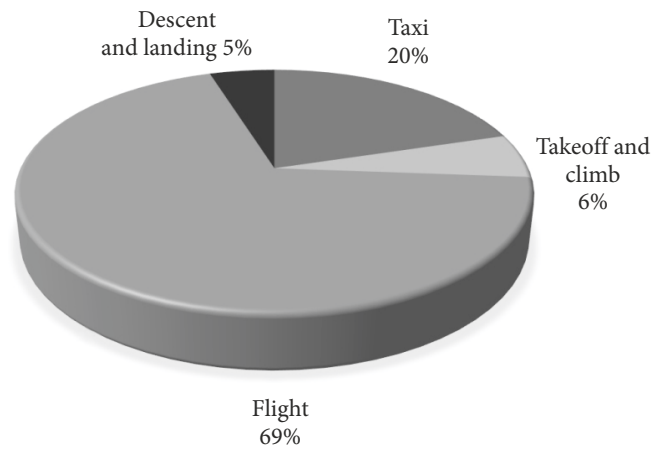

Figure 7. Mean time share of the given stages within the entire missions for flights $1,2,3$

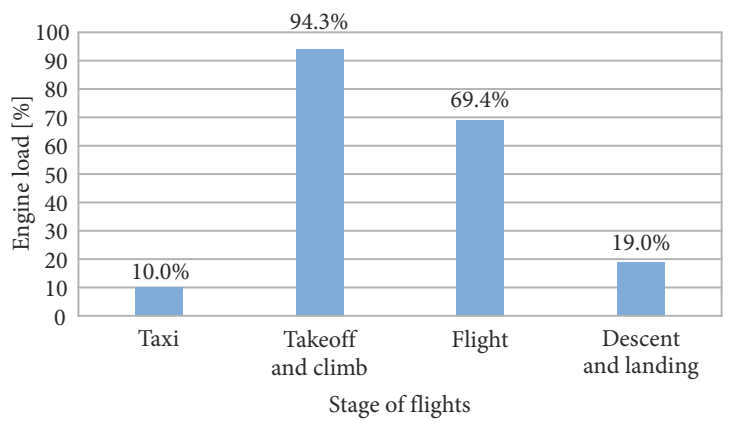

Figure 8. Mean engine load over the given stages for flights 1, 2, 3 
off and climb $13 \mathrm{~min}$, the cruise $216 \mathrm{~min}$ and the descent and landing $12 \mathrm{~min}$. The total time of the last flight time is $216 \mathrm{~min}$ where the taxiing takes $33 \mathrm{~min}$, the take-off and climb $16 \mathrm{~min}$, the cruise $155 \mathrm{~min}$ and the descent and landing $12 \mathrm{~min}$. The average values for the above data are as follows: the taxiing takes $40 \mathrm{~min}$, the take-off and climb $12 \mathrm{~min}$, the cruise $137 \mathrm{~min}$ and the descent and landing $10 \mathrm{~min}$.

The research results on the engine load should be examined in the same way. The engine load for the first flight over the taxiing is $10 \%$, the take-off and climb $95 \%$, the cruise $64 \%$ and $16 \%$ over the descent and landing, for the second flight the shares are 12, 92, 76 and 19\%, respectively, and for the third flight $8,96,68,22$, respectively. The averages for the given stages are as follows: $10 \%$ - the taxiing, 94.3\% - the take-off and climb, 69.4\% - the cruise, $19 \%$ - the descent and landing. It is essential that the Liberty XL2 flights are training flights so there are repeated take-offs and landings, and relatively short cruise times. The flight envelope developed in this research can be applied to calibration of the electronic control unit.

\section{Acknowledgements}

We would like to thank Aviation Training Centre of Rzeszów Technical University in Jasionka (Poland) for the opportunity to conduct research.

\section{Funding}

Without funding. There are no funders to report for this submission.

\section{Contribution}

Lukasz Grabowski: conception and design of the work, revising for important intellectual content. Zbigniew Czyz: analysis and interpretation of data, drafting the article. Marcin Porzak: acquisition of data, analysis and interpretation of data.

\section{Disclosure statement}

The authors declare that no conflict of interest, competing financial, professional, or personal interests from other parties.

\section{References}

ATSB. 2007. Engine Failure - $93 \mathrm{~km}$ East of Adelaide Airport, SA - 23 December 2005 -VH-OAE, British Aerospace Plc 3201, Jetstream. Australian Transport Safety Bureau (ATSB) Transport Safety Investigation Report. Aviation Occurrence Report 200506834 Final. 11 p. Available from Internet: https://www. atsb.gov.au/media/1362074/aair200506834_001.pdf

Austrian Technik. 2017. Company website. Available from Internet: https://www.austriantechnik.at

Bhaumik, S. K.; Rangaraju, R.; Venkataswamy, M. A.; Bhaskaran, T. A.; Parameswara, M. A. 2002. Fatigue fracture of crankshaft of an aircraft engine, Engineering Failure Analysis 9(3): 255-263. https://doi.org/10.1016/S1350-6307(01)00022-X
Bhaumik, S. K.; Sujata, M.; Venkataswamy, M. A. 2008. Fatigue failure of aircraft components, Engineering Failure Analysis 15(6): 675-694.

https://doi.org/10.1016/j.engfailanal.2007.10.001

Braly, G. W. 2016. Back to the Future: the Wright Aeronautical Division (WAD) Recommended Leaning Procedure. General Aviation Modifications, Inc. Available from Internet: http:// gami.com/articles/bttf.php

Brender, R. F.; Carney, T. Q. 2013. Comparison of best economy and best power mixture settings in the Purdue university training fleet revisited, Journal of Aviation Technology and Engineering 2(2):32-44. https://doi.org/10.7771/2159-6670.1074

Crane, D. 2010. Powerplant Test Guide 2011. Aviation Supplies \& Academics, Inc.

Dudziak, J. 2013. Analiza opłacalności stosowania silników tłokowych lub turbinowych do napędu śmigłowcóa lekkich, Prace Instytutu Lotnictwa 232-233(5-6): 15-23. (in Polish).

FAA. 2016. Pilot's Handbook of Aeronautical Knowledge. US Department of Transportation, Federal Aviation Administration (FAA). 524 p. Available from Internet: https://www.faa.gov/ regulations_policies/handbooks_manuals/aviation/phak

FAA. 2007. Type Certificate Data Sheet No. E7SO. Department of Transportation, Federal Aviation Administration (FAA). 4 p. Available from Internet: http://www.faa.gov

Findlay, S. J.; Harrison, N. D. 2002. Why aircraft fail?, Materials Today 5(11): 18-25. https://doi.org/10.1016/S1369-7021(02)01138-0

George, F. 2007. How they work: turbine engine fuel controls, Business \& Commercial Aviation 101(5): 38-41.

Guła, P.; Gorecki, T. 2013. Projekt, badania i wykonanie polskiego bezzałogowego śmigłowca ILX-27, Prace Instytutu Lotnictwa 232: 39-49. (in Polish).

Hajduk, J.; Sabak, R. 2013. Zagadnienia prób w locie bezzałogowego śmigłowca ILX-27, Journal of KONBiN 1: 45-58. (in Polish).

Hirschman, D. 2009. Frugal flyer: so wrong for so long, $A O P A$ Online 7. Available from Internet: https://www.aopa.org/ news-and-media/all-news/2009/july/pilot/frugal-flyer-sowrong-for-so-long

Kroes, M.; Wild, T. 1994. Aircraft Powerplants. McGraw-Hill Science/Engineering/Math. 656 p.

Lourenço, N. J.; Graça, M. L. A.; Franco, L. A. L.; Silva, O. M. M. 2008. Fatigue failure of a compressor blade, Engineering Failure Analysis 15(8): 1150-1154. https://doi.org/10.1016/j.engfailanal.2007.11.006

Menne, C. 2007. Full authority digital engine control, Malibu Mirage 16(3): 14-17. Available from Internet: http://www.malibuaerospace.com/docs/MMOPA\%20FADEC\%20Article.pdf

Ośrodek Kształcenia Lotniczego Politechniki Rzeszowskiej. 2018. Liberty Aerospace XL-2. Available from Internet: https://okl. prz.edu.pl/flota/liberty-aerospace-xl-2 (in Polish).

Rice, N. S. 1958. Basic Theory of Operation of the Turbo Compound Engine. Curtiss-Wright Corporation.

Stelak, M. 2010. Konstrukcje: Liberty XL-2 - Oryginał w każdym calu, Przegląd Lotniczy 4: 6-13. (in Polish).

Stone, R. 2012. Introduction to Internal Combustion Engines. 4th edition. Palgrave. 516 p.

Turan, D.; Karc1, A. 2009. Failure analysis of an aircraft piston engine components, Engineering Failure Analysis 16(4): 13391345. https://doi.org/10.1016/j.engfailanal.2008.09.022

Wendeker, M.; Czyż, Z. 2016. Analysis of the bearing nodes loads of turbine engine at an unmanned helicopter during a jump up and jump down maneuver, Eksploatacja i Niezawodność Maintenance And Reliability 18(1): 89-97. https://doi.org/10.17531/ein.2016.1.12 